\title{
Undifferentiated Carcinoma
} with Osteoclast-Like Giant Cells of the Pancreas Mimicking a Predominantly Calcified Mass: Case Report and Literature Review

\section{췌장에서 발생한 석회화 종괴로 오인된 파골세포양 거대세포를 가지는 미분화 암종: 증례 보고 및 문헌 고찰}

Tae Seop Choi, MD ${ }^{1}$ (D), Jongmee Lee, MD ${ }^{1 *}$ (D), Baek Hui Kim, MD², Jae Woong Choi, MD¹, Kyeong Ah Kim, MD${ }^{1}$, Cheol Min Park, MD ${ }^{1}$

Departments of ${ }^{1}$ Radiology, ${ }^{2}$ Pathology, Korea University Guro Hospital, Korea University College of Medicine, Seoul, Korea

Undifferentiated carcinoma with osteoclast-like giant cells (UCOGCS) of the pancreas is a rare neoplasm that contains osteoclast-like giant cells, which are morphologically identical to those seen in giant cell tumors of bones. Histopathologically, it is composed of round to spindleshaped neoplastic cells and non-neoplastic histiocytic giant cells. Although only limited radiologic findings are available due to the rarity of this tumor, UCOGCs shows variable imaging features in the literature from an inhomogeneous solid mass to a multilocular cystic tumor. Herein, we report an unusual manifestation of UCOGCs of the pancreas mimicking a predominantly calcified mass with radiologic-pathologic correlation.

Index terms Undifferentiated Carcinoma; Pancreas; Neoplasms; Computed Tomography, X-ray
Received April 18, 2018 Revised June 8, 2018 Accepted September 19, 2018

${ }^{\star}$ Corresponding author Jongmee Lee, MD Department of Radiology, Korea University Guro Hospital, Korea University

College of Medicine, 148 Gurodong-ro, Guro-gu, Seoul 08308, Korea.

Tel 82-2-2626-1338 Fax 82-2-863-9282

E-mail jongmee.lee@gmail.com

This is an Open Access article distributed under the terms of the Creative Commons Attribution Non-Commercial License (https://creativecommons.org/ licenses/by-nc/4.0) which permits unrestricted non-commercial use, distri-bution, and reproduction in any medium, provided the original work is properly cited.

\section{ORCID iDs}

Jongmee Lee (D) https:// orcid.org/0000-0002-6649-6120 Tae Seop Choi (D) https:// orcid.org/0000-0003-1092-1981

\section{INTRODUCTION}

Undifferentiated carcinoma with osteoclast-like giant cells (UCOGCs) is a rare pancreatic neoplasm, which was first described by Rosai in 1968 (1). It is composed of two distinct cell types; highly pleomorphic mononuclear cells and large, multinucleated, histiocytic giant cells, closely resembling giant cell tumors of the bone. Although 
UCOGCs is classified as a variant of ductal adenocarcinoma and mixed neoplasm of the pancreas (2), it shows unique clinical characteristics compared with pancreatic ductal adenocarcinoma.

Imaging findings for this unusual tumor are seldom reported because of its rarity. UCOGCs shows various radiologic features, frequently presenting as a multilocular cystic mass, an inhomogeneous mass with cystic change, or a strong, enhancing solid mass (3-5). To the best of our knowledge, an unusual manifestation mimicking a predominantly calcified mass of this tumor on CT scan has not yet been reported. In this report, we would like to describe the unusual imaging findings of UCOGCs of the pancreas mimicking a calcified mass on CT with a histopathological correlation.

\section{CASE REPORT}

A 53-year-old male patient visited our institution for evaluation of an incidentally detected pancreatic mass in an outside hospital. The patient had no specific clinical symptoms or past medical history. Blood tests revealed elevated glucose [165 mg/dL (74-106)] and HbA1c [8.5\% of $\mathrm{Hb}(4.0-6.0 \%)]$ levels. Results of other routine laboratory examinations, including tumor markers such as carbohydrate antigen 19-9 and carcinoembryonic antigen, were within normal ranges. The patient underwent CT scans at our institution using a 128-channel multidetector CT scanner (SOMATOM Definition AS, Siemens, Erlangen, Germany). Precontrast axial CT images revealed the presence of an approximately $5.8 \times 4$.3-cm-sized mass arising from the body of the pancreas that showed diffusely high attenuations (100-140 HU) within the mass, considered to represent calcifications (Fig. 1A). Contrast-enhanced axial CT scans of the pancreatic (Fig. 1B) and portal venous phases (Fig. 1C) demonstrated heterogeneously highly-enhanced foci within the mass and atrophic change of the distal part of the pancreas. The pancreatic mass abutted the posterior wall of the gastric high body.

Surgical resection (radical antegrade modular pancreatosplenectomy) was performed, revealing an approximately $4.6 \times 4.1-\mathrm{cm}$-sized hard mass at the pancreas body adhered to the

Fig. 1. CT findings of Undifferentiated carcinoma with osteoclast-like giant cells of the pancreas in a 53-year-old man.

A. Precontrast CT image reveals a predominantly high-attenuation mass $(100-140 \mathrm{HU})$, measuring $5.8 \times 4.3 \mathrm{~cm}$, considered to represent calcifications in the body of the pancreas (arrows).

B. Contrast-enhanced CT image at the pancreatic phase demonstrates heterogeneous, strong enhancement of the mass (arrows).

C. Contrast-enhanced CT image at the portal venous phase shows mild enhancement of the pancreatic mass and an atrophic change of the pancreas tail (arrowheads) without main pancreatic duct dilatation. The pancreatic mass directly invades the posterior wall of the gastric high body (arrow).
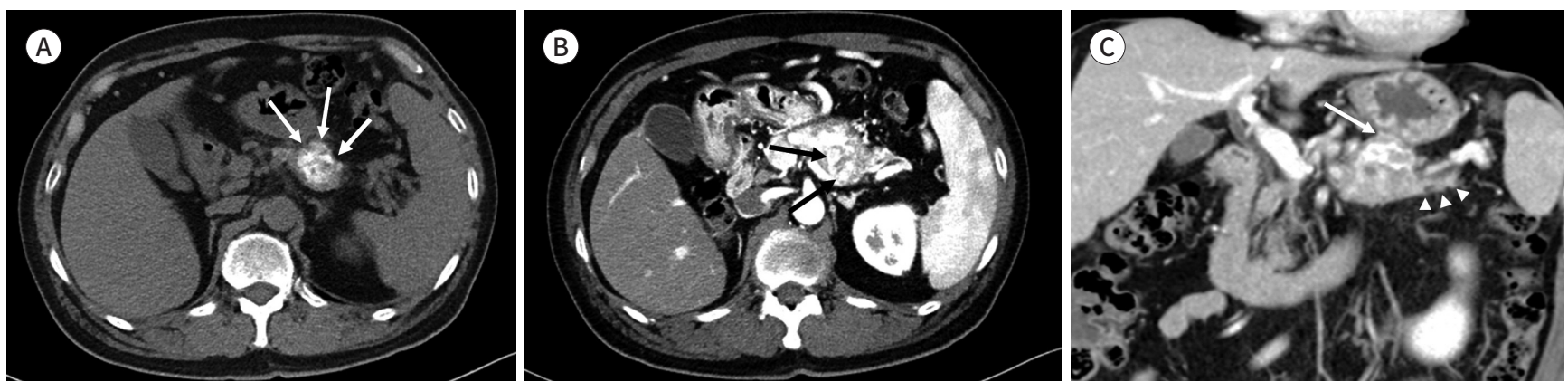
Fig. 1. CT findings of Undifferentiated carcinoma with osteoclast-like giant cells of the pancreas in a 53-year-old man.

D. Microscopically, a mixture of spindle-shaped, variably pleomorphic neoplastic cells and scattered multinucleated OGCs (arrows) among neoplastic cells are observed with hemorrhagic areas (H\&E, $\times 100)$. Ossifications were sparse within the tumor (not shown).

E, F. Immunohistochemical staining reveals strong reactivity for the histiocytic marker CD68 (E) in OGCs and some tumor cells and for vimentin (F) in neoplastic cells and OGCs (H\&E, $\times 200)$.

$\mathrm{H} \& \mathrm{E}=$ hematoxylin-eosin stain, OGCs = osteoclast-like giant cells
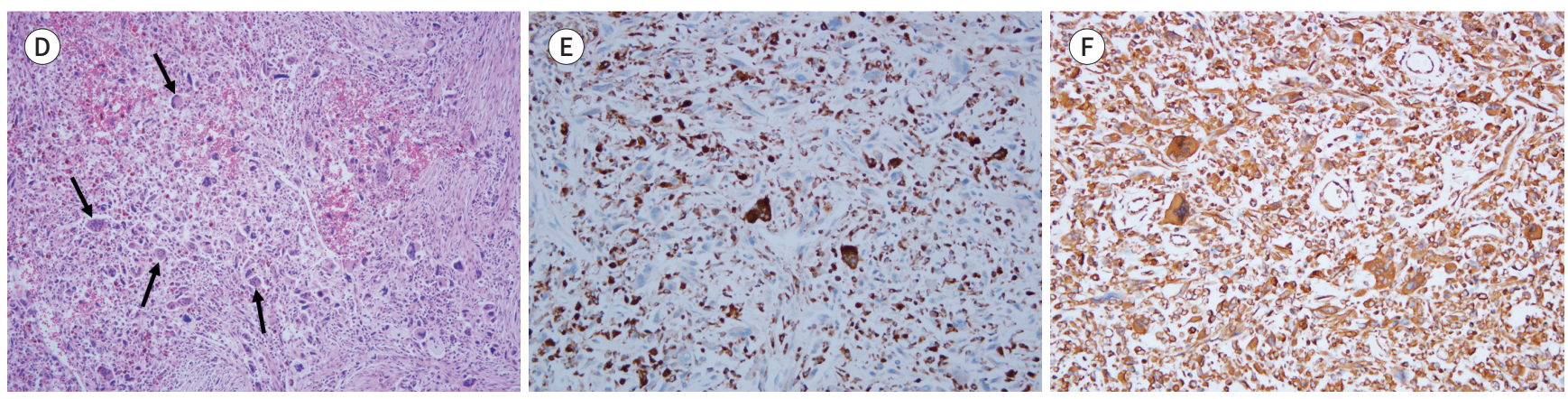

posterior wall of the gastric body in the operative field. Therefore, gastric wedge resection was also performed. On the cut section of the gross specimen, the tumor appeared as a redbrownish mass, showing profound hemorrhage. Microscopically, the mass was composed of spindle-shaped, variably pleomorphic neoplastic cells, as well as multinucleated osteoclastlike giant cells (OGCs), which were dispersed among the neoplastic cells (Fig. 1D). These cells encompassed hemorrhagic pools, and ossifications were sparsely detected within the tumor. Immunohistochemical staining revealed strong reactivity for the histiocytic marker CD68 in OCGs and some tumor cells (Fig. 1E), and for vimentin in neoplastic cells and OCGs (Fig. 1F). On the basis of these histopathologic findings, the tumor was diagnosed as an UCOGCs of the pancreas. For six months after surgery, there has been no evidence of recurrence.

\section{DISCUSSION}

UCOGCs of the pancreas is a rare, distinctive tumor type. There was a controversy on the nature and origin of this tumor; however, the World Health Organization has classified this tumor as a variant of ductal adenocarcinoma and mixed neoplasm of the pancreas since 2010 (2). Although the reported frequency of the tumor is variable, in the latest study with a large series of patients, the frequency of pancreatic carcinoma (ductal origin and its variants) was 1.4\% (10/735) (6). According to the literature, the average age of patients with UCOGCs of the pancreas is in the sixth to seventh decade, and this is younger than the average age in cases of pancreatic ductal adenocarcinoma (6). The body or tail portions of the pancreas tend to be involved (4). At the time of diagnosis, a large mass is usually present in the pancreas; therefore, more than $80 \%$ of tumors are larger than $5 \mathrm{~cm}$ (4). Despite their large size, nodal involvement and distant metastases are rarely observed; however, UCOGCs commonly invades adjacent structures (7).

UCOGCs is histologically characterized by round to spindle-shaped, highly pleomorphic mononuclear cells and large, multinucleated, histiocytic giant cells, closely resembling giant cell tumors of the bone. A previous study has shown that only the pleomorphic mononuclear cells constitute neoplastic tumor cells, while non-neoplastic OGCs are recruited to this neo- 
plasm (4). This type of tumor can occur in association with another pancreatic tumor, usually a ductal adenocarcinoma or a mucinous cystic neoplasm $(8,9)$. UCOGCs typically includes various degrees of hemorrhage and necrosis, and non-neoplastic OGCs are often found in areas adjacent to hemorrhage. Immunohistochemically, the majority of the neoplastic mononuclear cells express vimentin, and some label with antibodies to p53. In contrast, OGCs express CD68, vimentin, and leukocyte common antigen, but do not label with antibodies to p53 $(2,8)$. These findings confirm an epithelial origin for UCOGCs.

Radiologic findings of pancreatic UCOGCs are not well established, and variable radiologic features have been reported in the literature. It is commonly seen as a large, solid and cystic neoplasm with varying degrees of hemorrhage and necrosis (7). This finding reflects the rapid growth of the tumor. If the cystic component becomes predominant due to necrosis or hemorrhage, it can be described as a multilocular cystic tumor (3). On the other hand, Shindoh et al. (5) reported a strongly enhanced solid mass in the head and body of the pancreas with dilatation of the biliary and pancreatic ducts, suggesting that strong arterial enhancement of the mass is one of the characteristics of UCOGCs. This hypervascular nature of UCOGCs can be attributed to its histologic similarity to giant cell tumors of the bone. However, significant hemorrhage and necrosis can change the nature of the contrast-enhancement pattern of the tumor. In some reports, intraductal or intracystic tumor growth were identified as unique features, accompanied by pancreatic ductal dilatation (6). MR imaging findings of UCOGCs are limited. On MR imaging, it appeared as a low to dark signal intensity mass on T1- and T2-weighted images and shows heterogeneous high signal intensity in the central area due to necrosis. Because of the low signal intensity on T2-weighted image, diffusion restriction of the tumor was not prominently visualized (10).

In our patient, UCOGCs demonstrated a heterogeneous, well-enhanced solid mass in the pancreas body on contrast-enhanced CT scans. These findings are similar to those of previous reports. Precontrast CT scan images delineated predominantly high attenuation areas within the tumor, considered to represent calcifications. In several reports, precontrast CT scan images revealed tiny calcifications in septations or subtle high attenuation at the periphery of the mass $(3,10)$. To the best of our knowledge, there have been no reports of radiologic findings showing a predominantly calcified mass for UCOGCs of the pancreas, as it does in our study. Although ossifications were identified within the tumor on histopathological examination, they were too sparse to show high attenuation on precontrast CT. Profound, multifocal hemorrhages inside the tumor, which were observed in cut sections of the gross specimen, are presumed to cause high attenuation areas mimicking calcifications.

Although an accurate pretreatment diagnosis is essential to determine the most appropriate treatment for pancreatic UCOGCs, because of its rarity and various radiologic findings, it is difficult to diagnose this tumor preoperatively; most cases were diagnosed after pancreatectomy (8). The differential diagnosis of pancreatic UCOGCs includes cystic lesions, such as serous and mucinous cystic neoplasms; cystic change of the solid mass, including ductal adenocarcinoma and neuroendocrine tumor; and pancreatic pseudocyst. With regard to a differential diagnosis for solid mass, neuroendocrine tumor and metastasis should be included considering the hypervascular nature of the tumors. However, a variable degree of enhancement of the tumor is possible depending on the hemorrhage and necrosis inside the tumor, 
ductal adenocarcinoma or solid pseudopapillary neoplasm can also be considered as a differential diagnosis $(3,5,7,10)$.

The prognosis of pancreatic UCOGCs is known to be better than that of ductal adenocarcinoma, because perivascular lymphatic spread is rare and metastatic spread is slower (7). A recent study reported that UCOGCs has a better prognosis than the current impression in the literature, with a median survival period of 7.67 years (6).

In conclusion, UCOGCs of the pancreas is a rarely encountered, malignant neoplasm with unique clinical and pathological characteristics. It can show variable CT features from an inhomogeneous solid mass to a multilocular cystic tumor. UCOGCs of the pancreas can mimic a predominantly calcified lesion, as it does in our study; thus, this finding is potentially valuable for the diagnosis of UCOGCs of the pancreas.

\section{Conflicts of Interest}

The authors have no potential conflicts of interest to disclose.

\section{REFERENCES}

1. Rosai J. Carcinoma of pancreas simulating giant cell tumor of bone. Electron-microscopic evidence of its acinar cell origin. Cancer 1968;22:333-344

2. Fukushima N, Hruban RH, Kato Y, Klimstra DS, Kloppel G, Shimizu M, et al. Ductal adenocarcinoma variants and mixed neoplasms of the pancreas. In Bosman FT, Carneiro F, Hruban RH, Theise ND, eds. WHO classification of tumours of the digestive system. Lyon: IARC Press 2010:292-295

3. Ichikawa T, Federle MP, Ohba S, Ohtomo K, Sugiyama A, Fujimoto H, et al. Atypical exocrine and endocrine pancreatic tumors (anaplastic, small cell, and giant cell types): CT and pathologic features in 14 patients. Abdom Imaging 2000;25:409-419

4. Bauditz J, Rudolph B, Wermke W. Osteoclast-like giant cell tumors of the pancreas and liver. World J Gastroenterol 2006;12:7878-7883

5. Shindoh N, Ozaki Y, Kyogoku S, Nakanishi A, Sumi Y, Katayama H. Osteoclast-type giant cell tumor of the pancreas: helical CT scans. AJR Am J Roentgenol 1998;170:653-654

6. Muraki T, Reid MD, Basturk O, Jang KT, Bedolla G, Bagci P, et al. Undifferentiated carcinoma with osteoclastic giant cells of the pancreas: clinicopathologic analysis of 38 cases highlights a more protracted clinical course than currently appreciated. Am J Surg Pathol 2016;40:1203-1216

7. Gao HQ, Yang YM, Zhuang Y, Liu P. Locally advanced undifferentiated carcinoma with osteoclast-like giant cells of the pancreas. World J Gastroenterol 2015;21:694-698

8. Molberg KH, Heffess C, Delgado R, Albores-Saavedra J. Undifferentiated carcinoma with osteoclast-like giant cells of the pancreas and periampullary region. Cancer 1998;82:1279-1287

9. Joo YE, Heo T, Park CH, Lee WS, Kim HS, Kim JC, et al. A case of osteoclast-like giant cell tumor of the pancreas with ductal adenocarcinoma: histopathological, immunohistochemical, ultrastructural and molecular biological studies. J Korean Med Sci 2005;20:516-520

10. Yang KY, Choi JI, Choi MH, Park MY, Rha SE, Byun JY, et al. Magnetic resonance imaging findings of undifferentiated carcinoma with osteoclast-like giant cells of pancreas. Clin Imaging 2016;40:148-151 


\section{췌장에서 발생한 석회화 종괴로 오인된 파골세포양 거대세포를 가지는 미분화 암종: 증례 보고 및 문헌 고찰}

최태섭 ${ }^{1} \cdot$ 이종미 $\left.\right|^{*} \cdot$ 김백희 $^{2} \cdot$ 최재웅 1 김경아 ${ }^{1} \cdot$ 박철민 $^{1}$

췌장에 발생하는 파골세포양 거대세포를 가지는 미분화 암종은 골의 거대세포종과 형태학 적으로 동일한 파골세포양 거대세포를 가지는 매우 드문 종양이다. 이 종양은 조직학적으로 난형 또는 방추형의 종양세포와 조직구양 거대세포인 비종양세포로 구성된다. 파골세포양 거대세포를 가지는 미분화 암종의 희소성 때문에 알려진 영상의학적 소견이 제한적이지만, 불균일한 고형 종괴부터 다방 낭성 종괴까지 다양한 영상 소견이 보고되어 있다. 저자들은 파골세포양 거대세포를 가지는 미분화 암종이 주로 석회화된 종괴로 오인된 매우 드문 소견 에 대해 문헌 고찰과 함께 보고하고자 한다.

고려대학교 의과대학 구로병원 ${ }^{1}$ 영상의학과, ${ }^{2}$ 병리과 